\title{
Persepsi Kontributor Televisi tentang Keberadaan Citizen Journalism
}

\author{
Perception of Television Contributors on the Existence of Citizen \\ Journalism \\ Nurul Hasanah*, Ramdeswati Pohan \\ Program Studi Jurnalisme \\ Sekolah Tinggi Ilmu Komunikasi “Pembangunan" Medan, Indonesia \\ ${ }^{*}$ Corresponding Author, Email: Nurulhasanah916@gmail.com
}

\begin{abstract}
Abstrak
Tujuan dari penelitian ini, yang pertama adalah untuk mengetahui bagaimana persepsi dan komunikasi yang terbentuk antara kontributor televisi dan Citizen Journalism. Kedua adalah untuk mengetahui bagaimana faktor dan dampak yang ditimbulkan dari keberadaan Citizen Journalism dan bagaimana etika Citizen Journalism di lapangan saat peliputan. Penelitian ini menggunakan metode kualitatif deskriptif dengan pengumpulan data berupa wawancara, observasi, dokumentasi serta studi kepustakaan. Penelitian ini menggunakan teori Behaviorisme dari Gage dan Berliner, dimana teori Behaviorisme ini mendasarkan perubahan tingkah laku pada pengalaman, perilaku dan respon. Pada dasarnya inti pemikiran Behaviorisme adalah bagaimana memahami perilaku yang dikendalikan oleh faktor-faktor lingkungan. Selain itu peneliti juga menggunakan teori Persepsi, yang mengkaji bagaimana komunikasi terjalin berdasarkan penginderaan, atensi dan interpretasi. Teori ini berasumsi bahwa persepsi menentukan seseorang bagaimana sikapnya berkomunikasi, semakin tinggi derajat kesamaan persepsi antar individu maka semakin mudah dan sering mereka berkomunikasi yang kemudian memiliki pengaruh yang instrumental terhadap hasil-hasil kesimpulan. Hasil penelitian yang didapat adalah faktor-faktor yang terjadi dengan keberadaan Citizen Journalism yang di peroleh dari informasi berupa pengalaman dan pengetahuan melalui kesadaran mereka dan bagaimana mereka memaknai pengalaman tersebut dalam berinteraksi.
\end{abstract}

Kata Kunci: Citizen Journalism, Kontributor Televisi, Behaviorisme dan Persepsi.

\begin{abstract}
The purpose of this study, the first is to find out how perceptions and communication formed between television contributor and Citizen Journalism. Second is to know how the factors and impacts caused by the existence of Citizen Journalism, and how Citizen Journalism ethics in the field of coverage. This research uses qualitative descriptive method with data collection in the form of interview, observation, documentation, and literature study. This study uses the theory of Behaviorism from Gage and Berliner, where the theory of Behaviorism is based on behavioral changes in experience, behavior, and response. Basically the core idea of Behaviorism is how to understand behavior that is controlled by environmental factors. In addition researchers also used the theory of perception, which examines how communication is established based on sensing, attention and interpretation. This theory assumes that perception determines a person how his attitude communicates, the higher the degree of common perception between individuals the easier and often they communicate which then has an instrumental influence on the results of the conclusions. The results obtained are the factors that occur with the presence of Citizen Journalism obtained from information in the form of experience and knowledge through their awareness and how they interpret the experience in interacting.
\end{abstract}

Keywords: Citizen Journalism, Contributors Television, Behaviorism and Perception.

How to Cite: Hasanah, N., Ramdeswati, P., (2018), Persepsi Kontributor Televisi tentang Keberadaan Citizen Journalism, SIMBOLIKA, 4 (1): 15-23. 


\section{PENDAHULUAN}

Belakangan ini, media massa
berkembang sangat pesat. Seiring
perkembangan teknologi informasi dan
komunikasi yang sangat maju. Media massa
merupakan salah satu kebutuhan utama bagi
masyarakat karena memudahkan khalayak
untuk mendapatkan informasi, baik dari
dalam negeri maupun mancanegara.

Di era teknologi digital perkembangan jurnalistik juga semakin pesat, selaras dengan perkembangan kesadaran masyarakat untuk memperoleh informasi. Kesadaran masyarakat tersebut membuat sebagian kalangan masyarakat tertarik untuk berkecimpung dalam dunia kejurnalistikan. Sehingga hampir di setiap media di Indonesia memiliki rubrik ruang publik. Selain memberikan aspirasi, masyarakat awam dapat terjun langsung menjadi seorang jurnalis amatir. Sebagian kalangan masyarakat seperti dosen, guru, pejabat, mahasiswa dan pelajar memiliki kesempatan yang lebih terbuka dan luas untuk menyampaikan informasi.

Hal tersebut akan meningkatkan wawasan masyarakat agar semakin bertambah luas. Karena dengan pekanya terhadap informasi baru maka akan menimbulkan kesadaran pentingnya informasi di kalangan masyarakat. Bukan hanya media massa dan jurnalistik yang berkembang, saat ini masyarakat yang umumnya penikmat media massa juga berkembang sangat cepat. Salah satu fenomena yang terjadi saat ini adalah hadirnya media sosial yang dapat menyebarkan informasi apa saja mengenai kejadian yang telah mereka alami ataupun kejadian yang terjadi di sekitar mereka.

Masyarakat umum dapat menampilkan karya-karya jurnalistik mereka di berbagai media massa atau media sosial sehingga lahirlah istilah Citizen Journalism yaitu jurnalisme yang dilakukan warga. Kegiatan jurnalisme warga dalam menyebarluaskan informasi kepada publik bisa saja seperti yang dilakukan oleh jurnalis profesional. Informasi dapat dikemas dalam bentuk tulisan, gambar, foto dan video yang disebarluaskan pada media massa maupun media sosial melalui internet. Televisi setiap harinya menyajikan berbagai jenis program yang jumlahnya sangat banyak dan jenisnya sangat beragam. Pada dasarnya apa saja bisa dijadikan program untuk ditayangkan di televisi selama program itu menarik dan disukai audien dan selama tidak bertentangan dengan kesusilaan, hukum dan peraturan yang berlaku (Morrisan, 2011: 217).

Program televisi sebagai faktor yang paling penting dalam mendukung finansial suatu penyiaran radio dan televisi adalah program yang membawa audien mengenal suatu penyiaran. Berbagai jenis program televisi tersebut dapat dibagi menjadi beberapa jenis, yaitu (Morrisan, 2011: 217): Citizen journalism (selanjutnya disebut cj) akhir-akhir ini menjadi perbincangan para pakar media internasional karena di beberapa negara ternyata memiliki kemampuan menjadi media alternatif bagi warga, bahkan pada beberapa kasus menyaingi eksistensi jurnalisme profesional dalam hal ini televisi, surat kabar dan radio. Perkembangan cj memungkinkan masyarakat Indonesia memiliki akses untuk menjadi subyek dalam pemberitaan. Masyarakat juga mendapat kesempatan menyuarakan aspirasinya karena memiliki ruang di media.

Hal ini penting mengingat media massa, meski berada di dalam lingkup negara yang memiliki kebebasan pers tetap memiliki keterbatasan misalnya kecondongan pada berbagai kepentingan terutama kapital dan politis. Dengan demikian maka penting untuk menyambut $c j$ yang diharapkan akan memberikan warna tersendiri yang lebih independen dan jujur di dunia media di Indonesia.

Cj mulai berkembang pada tahun 1988 di Amerika Serikat. Jay Rossen, dosen Universitas New York yang memperkenalkan genre jurnalistik ini kepada warga Amerika 
Serikat melalui media online. Sementara itu di Indonesia, siaran-siaran radio yang berbasiskan komunitas menjadi pelopor lahirnya $c j$, yaitu lewat partisipasi aktif pendengar terhadap siaran berita. Radio tersebut memiliki jam-jam khusus untuk menerima telepon atau membacakan pesan dari masyarakat yang isinya mengenai berita yang terjadi di sekitar warga. Mulai dari kecelakaan, lalu lintas, hingga pungli yang dilakukan oknum yang tidak bertanggung jawab http://repository.fisipuntirta.ac.id/313/6/skripsi\%20revisi $\% 20 \% 2$ 8Repaired\%29.pdf.

Perkembangan jurnalisme warga di Indonesia sendiri pertama kali di tahun 2004 saat bencana Tsunami di Aceh, seorang warga yang bernama Cut Putri merekam video kejadian Tsunami yang menerjang Aceh yang kemudian hasil rekamannya di tayangkan oleh stasiun televisi MetroTV. Kegiatan ini terus berkembang sejalan dengan hadirnya teknologi informasi dan makin banyaknya pengguna internet dalam bentuk blog di tahun 2000-an. Walaupun terbilang sebagai jurnalisme baru, namun kegiatannya banyak memberi kesempatan pada masyarakat untuk dapat berpartisipasi. Karena dalam $c j$, tiap orang bisa menjadi jurnalis dan ikut menyampaikan informasi kepada publik. $c j$ dapat dinilai sebagai bentuk partisipasi aktif masyarakat untuk menyalurkan pendapatnya secara lebih leluasa, terstruktur, serta dapat diakses secara umum sekaligus menjadi rujukan alternatif.

Cj merupakan kegiatan dimana peran wartawan atau kegiatan jurnalistik bisa dilakukan oleh masyarakat yang secara formal bukan wartawan. Kegiatan yang dilakukan sama dengan wartawan pada umumnya, yakni mengumpulkan informasi, menulis berita, mengedit, dan menyiarkannya. Dalam penyiaran informasinya, $c j$ bisa mengirim tulisannya pada media massa seperti koran, media online mapupun stasiun televisi, kemudan redaksi memutuskan apakah tulisan atau video tersebut layak atau tidak dipublikasikan melalui media massanya (Modul workshop film dan video citizen journalism, 2017).

Pada saat ini kemunculan $c j$ mulai hadir di media elektronik khususnya televisi. Beberapa media televisi kini juga menghadirkan program khusus $c j$ yang memuat hasil karya jurnalistik warga. Stasiun televisi yang menghadirkan program $c j$ di Indonesia saat ini, beberapa diantaranya adalah Metro TV dengan program Wide Shot, Net TV dengan program Net $c j$, Kompas TV dengan program \#Laporanwarga dan Trans 7 dengan program Cam On. Saat ini $c j$ menjadi salah satu program andalan televisi tersebut.

Dalam perkembangannya $c j$ mendapat banyak pro dan kontra dari berbagai pihak khususnya jurnalis, tidak dapat disangkal sebagian institusi pers dan jurnalis profesional yang bekerja pada media arus utama masih memandang pesimis cj sebagai "barang yang kurang berguna". Akan tetapi, sebagian institusi pers menganggap $c j$ adalah challenge atau tantangan yang harus diperlakukan untuk melengkapi media arus utama. Dengan sendirinya, pewarta warga menjadi bermanfaat dan menjadi pelengkap media arus utama (Nugraha, 2012: 36).

Hadirnya citizen journalism dirasakan bukan hanya sebagai demokratisasi media, tapi sebagai wadah partisipasi masyarakat sebagai subjek maupun objek informasi. Kegiatan citizen journalism banyak berkontribusi dalam mewujudkan masyarakat informasi. Bentuk partisipasi inilah yang menarik untuk dikaji, apakah partisipasi merupakan sebuah kepekaan dan kepedulian terhadap informasi yang saat ini dikuasai oleh media mainstream, atau karena adanya reward berupa hadiah yang diberikan media massa, ataupun karena mereka ingin menunjukkan eksistensi keberadaannya melalui ruang publik. Serta bagaimana para pelaku citizen journalism memaknai diri mereka sebagai jurnalis warga, dan sampai sejauh mana 
bentuk partisipasi masyarakat dalam citizen journalism itu sendiri ditambah dengan tidak adanya batasan peliputan prosedur dan kurangnya pengetahuan mengenai etika di dalam dunia jurnalistik http://repository.fisip-

untirta.ac.id/313/6/skripsi\%20revisi $\% 20 \% 2$ 8Repaired\%29.pdf.

Kehadiran $c j$ menimbulkan berbagai persepsi baik positif atau negatif khususnya di kalangan jurnalis. Menurut hasil penelitian yang merupakan tesis yang dibuat oleh mahasiswa Master Art in Journalism Ateneo de Manila University, Moch. Nunung Kurniawan tahun 2006, beberapa praktisi media di Indonesia masih menjaga jarak dengan online media. Mereka berpendapat wartawan profesionallah yang melakukan tugas jurnalistik karena sudah dibekali dengan kemampuan peliputan yang mumpuni dan dibimbing dengan kode etik jurnalistik. Hal lain yang menunjukkan bahwa masih banyak yang masih meragukan karena akan turunnya kredibilitas portalnya, kemungkinan masalah hukum dan kurangnya pemahaman atas kode etik jurnalistik dari reporter warga. Mereka juga tidak menampilkan berita dari warga hanya menindak lanjuti laporan dari warga http://eprints.undip.ac.id/7226/1/journalism _globalisasi_informasi.pdf.

Ada beberapa kasus yang dikemukakan kontributor televisi terhadap peneliti mengenai $c j$. Kasus yang pertama ialah dimana seorang $c j$ yang melakukan peliputan memberi pengakuan identitas di suatu media kepada narasumber. Hal ini, yang kemudian menjadi masalah terhadap jurnalis professioal yang disebutkan $c j$ tersebut ada bentrokan pendapat jika jurnalis professional tersebut melakukan peliputan yang sama. Kasus lain dimana citizen melakukan peliputan yang menyimpangkan menyalahi etika jurnalistik maupun etika perbuatan atau sikap, hal ini lah yang sangat disayangkan oleh jurnalis professional atau kontributor. Namun pada dasarnya kedua belah pihak ini sangat berkaitan dan saling membantu dalam penyampaian informasi kepada khalayak.

Fenomena kehadiran $c j$ memang merupakan sebuah realitas. Pemaknaan terhadap realitas ini bisa saja bersifat objektif, namun bisa pula subjektif. Hal itu tergantung pada konstruksi yang dibentuk oleh tiap orang yang menilainya, karena setiap orang memiliki cara yang berbeda-beda dalam mengkonstruksi fenomena yang terjadi.

\section{METODE PENELITIAN}

Metode penelitian adalah prosedur atau cara dalam melakukan penelitian untuk menjawab tujuan penelitian. Dapat meliputi penemuan, pembuktian dan pengembangan ilmu pengetahuan. Adapun kegunaan penelitian meliputi untuk memahami masalah (hasil penelitian digunakan untuk memperjelas suatu masalah atau informasi yang tidak diketahui dan selanjutnya diketahui), memecahkan masalah dan mengantisipasi masalah. Berdasarkan penjelasan tersebut metode penlitian adalah prosedur yang dilakukan dalam kegiatan penelitian dengan memperhatikan kaidah ilmiah dan pencapaian tujuan penelitian (Pujileksono, 2015:4).

Penelitian kualitatif adalah penelitian yang bermaksud untuk memahami fenomena tentang apa yang dialami oleh subjek penelitian misalnya perilaku, persepsi, motivasi, tindakan dan lain-lain, secara holistik, dan dengan cara deskriptif dalam bentuk kata-kata dan bahasa, pada suatu konteks khusus yang lamiah dan dengan memanfaatkan berbagai metode alamiah (Moleong, 2014:6).

Dalam penelitian ini, penelitian menggunakan metode penelitian deskriptif kualitatif. Dikarenakan, agar peneliti lebih memahami fenomena dengan cara memberikan penggambaran yang tentang fenomena tersebut dalam bentuk rangkaian kata. Metode sampling adalah pembicaraan bagaimana menata berbagai teknik dalam 
penarikan atau pengambilan sampel penelitian, bagaimana kita merancang tata cara pengambilan sampel agar menjadi sampel yang representatif. Dengan tidak melupakan beberapa faktor yang harus dipertimbangkan dalam memperoleh sampel yang representatif, peneliti memulai mengenal keseragaman dan ciri-ciri khusus populasi (Bungin, 2005: 115).

Subjek pada penelitian difokuskan secara sengaja dengan istilah informan. Informan menjadi sumber informasi selama diadakannya proses penelitian. Pada penelitian ini menggunakan jenis informan utama yakni subjek penelitian yang terlibat dalam penelitian secara langsung. Metode penarikan sampel dalam penelitian sosial pada dasarnya meliputi teknik random dan nonrandom. Dalam penelitian ini teknik yang digunakan peneliti adalah purposive sampling dimana teknik pengambilan responden dilakukan secara sengaja berdasarkan pertimbangan tertentu sesuai dengan tujuan penelitian. Proses penggunaan teknik ini berdasarkan keputusan peneliti yang memilih sejumlah elemen secukupnya dari populasi yang menurut pendapatnya mewakili populasi (Hikmat, 2011:66).

Dalam teknik pengumpulan data, peneliti menggunakan berbagai teknik, antara lain: penelitian lapangan (Field Research) dengan mengumpulkan data dan menyusunnya, peneliti menetapkan teknik dan alat data sebagai berikut: 1) Observasi merupakan pengamatan langsung keadaan di lapangan atau di mana objek itu berada. Dalam menggunakan metode obervasi cara yang paling efektif adalah melengkapinya dengan format atau blangko pengamatan sebagai instrumen. (Arikunto, 1993:199). Kegiatan observasi meliputi melakukan pencatatan secra sistematik kejadian-kejadian, perilaku, objek-objek yang dilihat dan hal-hal lain yang diperlukan dalam mendukung penelitian yang sedang dilakukan. 2) Wawancara, merupakan teknik pencarian data atau informasi mendalam yang diajukan kepada responden atau informasi mendalam yang diajukan kepada responden atau informasi dalam bentuk pertanyaan susulan setelah teknik observasi dalam bentuk pertanyaan lisan. Ini sangat diperlukan untuk mengungkapkan bagian terdalam yang tidak terungkap lewat observasi. 3) Penelitian kepustakaan dilakukan dengan cara mengumpulkan data melalui literatur dan bacaan yang mendukung. Hal tersebut menunjukan bahwa fungsi perpustakaan tidak lagi semata-mata sebagai sarana edukatif dan rekreatif, tetapi juga sebagai sarana informatif dan inovatif, sejalan secara simbiosis bagi kepentingan penelitian dan ilmu.

Analisis data dilakukan dengan mengorganisasikan data, menjabarkannya ke dalam unit-unit, melakukan sintesa, menyusun ke dalam pola, memilih mana yang penting dan membuat kesimpulan yang dapat diceritakan kepada oranglain. (Sugiyono: 2014 : 88). Proses analisis data dalam penelitian kualitatif dilakukan sejak sebelum memasuki lapangan, selama di lapangan, dan setelah selesai di lapangan. Namun dalam penelitian kualitatif, analisis data lebih difokuskan selama proses dilapangan bersama dengan pengumpulan data. Dalam kenyataanya, analisis data kualitatif berlangsung selama proses pengumpulan data dari pada setelah selesai pengumpulan data (Sugiyono, 2014: 89).

Aktivitas dalam analisis data, yakni: 1) Reduksi data berarti merangkum, memilih halhal yang pokok, memfokuskan pada hal-hal yang penting, dicari tema dan polanya. Dengan demikian data yang telah direduksi akan memberikan gambaran yang lebih jelas, dan mempermudah peneliti untuk melakukan pengumpulan data selanjutnya, dan mencarinya bila perlu. Reduksi data dapat dibantu dengan peralatan elektronik seperti komputer mini. Reduksi data merupakan analisis yang menajamkan untuk 
mengorganisasikan data, dengan demikian kesimpulannya dapat diverifikasi untuk dijadikan temuan penelitian terhadapa masalah yang diteliti. 2) Penyajian data yang akan memudahkan untuk memahami apa yang terjadi, merencanakan kerja selanjutnya berdasarkan apa yang telah dipahami. Dalam penyajian data peneliti dapat dianalisis oleh peneliti untuk disusun secara sistematis, atau stimultan sehingga data yang diperoleh dapat menjelaskan atau menjawab masalah yang diteliti. Maka penyajian data peniliti disarankan utnuk tidak gegabah mengambil kesimpulan. 3) Kesimpulan dalam penelitian mungkin dapat menjawab rumusan masalah, karena rumusan masalah dalam penelitian kualitatif masih bersifat sementara dan berkembang setelah peneliti berada di lapangan. Kesimpulan penelitian kualitatif disajikan berupa deskripsi atau gambaran yang awalnya belum jelas menjadi jelas dan dapat berupa hubungan kausal/interaktif dan hipotesis/teori. Penarikan kesimpulan dan verifikasi dilakukan setelah dari lapangan

\section{HASIL DAN PEMBAHASAN}

Poin utama dari perbedaan $c j$ dengan Kontributor Televisi, dari keterikatan kontrak kerja dengan suatu media dan tanggungjawab masing-masing. Informan berpendapat $c j$ memiliki kebebasan dalam memilih media mana yang akan ia kirim berita atau karya jurnalistiknya dan juga bebas untuk kapan saja membuat berita. Identitas atau kartu tanda pengenal media menjadi ciri utama perbedaan $c j$ dengan Kontributor, karena $c j$ tidak dibekali kartu pers atau surat penugasan.

Berkaitan dengan penugasaan atau peliputan di lapangan, kontributor tidak banyak mengalami interaksi dengan $c j$ saat di daerah peliputan. Interaksi informan dengan cj tidak sering menjalani komunikasi, kadang informan terlebih dahulu menyapa $c j$ yang lebih awal ada dilokasi peliputan untuk menanyakan baik informasi ataupun video awal peristiwa. Namun terkadang informan mengalami kesulitan saat meliput peristiwa karena warga setempat menjadi $c j$ dadakan atau merekam saat dilokasi kejadian dan menganggu kinerja Kontributor di lapangan.

Berkembangnya teknologi membuat informasi mudah diakses bahkan warga biasa pun bisa menginformasikan langsung kepada masyarakat luas hanya dengan telepon gengam atau Handphone. Namun hal ini tidak diimbangi dengan pengetahuan mengenai kode etik jurnalistik, baik secara visual maupun pemilikan etika saat di lapangan atau lokasi kejadian. $C j$ yang mengerti akan aturan akan sangat membantu tetapi $c j$ yang tidak mengerti aturan bahkan melanggar aturan jurnalistik sangat mengganggu kinerja Kontributor Televisi. Hal ini kemudian berpengaruh dengan pertanyaan yang peneliti ajukan mengenai kesan informan terhadap $c j$.

Ada kesan baik dengan $c j$ yang ditemuinya dari kalangan mahasiswa, karena memiliki cara pandang luas dan baik dalam beretika, dibanding masyarakat awam. Informan merasa etika sangat penting karena untuk mengurangi penyimpangan sikap dalam dunia jurnalistik ketika di daerah peliputan. Penyimpangan terjadi saat Citizen Journalism merasa dirinya menjadi bagian dari media tersebut karena berita yang dikirimnya selalu tayang dan $c j$ sudah beralih fungsi dari hanya menginformasikan untuk kepentingan khalayak menjadi profesi/pekerjaan seperti selayaknya seorang jurnalis. Penyimpangan tersebut sangat terlarang bahkan untuk kontributor televisi sekalipun.

Setiap profesi mempunyai aturan atau kode etik yang berlaku dan wajib di ikuti, dalam hal ini kontributor televisi yang melakukan pelanggaran mendapatkan sangsi yang diberikan oleh media tempat ia bekerja, hingga menjadikan kontributor tidak bebas atau leluasa dalam melakukan hal yang menyimpang tersebut. Namun hal ini tidak berlaku bagi citizen journalism. Peraturan mendasar dalam peliputan $c j$ menurut 
informan belum ada, hanya saja ada pengawasan khusus dari pemerintah yang diatur dalam undang-undang ITE, tetapi hal ini tidak mengurangi penyimpang berupa penyalahgunaan nama media demi kepentingan pribadi. Adapun saran atau masukan yang diberikan informan untuk konsep citizen journalism yang saat ini berkembang pesat.

Ada pembatasan mengenai arti dari $c j$ dan kontributor televisi karena minimnya pengetahuan warga mengenai arti $c j$ sebenarnya. Bagaimana awal kemunculan dari cj sendiri menurut informan. Kemunculan citizen jurnalism sangat dipengaruhi oleh perkembangan teknologi yang kian melesat dan juga dipengaruhi oleh media sosial yang saat ini menjadi sangat popular karena kecepatan dalam penyebaran informasi. Namun masyarakat umumnya tidak peduli tentang kode etik jurnalistik dan akurasi berita mana yang layak dan tidak layak, masyarakat hanya peduli tentang kecepatan penyebaran informasi, Padahal hal tersebut sangat dipatuhi oleh kontributor televisi. Lalu bagaimana padangan informan mengenai kontributor televisi.

Kontributor mempunyai tugas dan tanggungjawab yang wajib dilaksanakan, dari hasil wawancara ini peneliti melihat untuk menjadi kontributor harus mempunyai bekal pengetahuan yang luas, baik dalam bidang jurnalistik maupun teknologi. lalu apa yang membedakan kontributor televisi dengan Citizen Journalism menurut informan. Secara resmi yang membedakan kontributor degan citizen journalism adalah keterikatan dengan media, karena kontributor merupakan profesi sedangkan citizen journalism hanya wadah masyarakat menyampaikan aspirasinya melalui media massa. Namun apakah keberadaan $c j$ berpengaruh dengan kinerja kontributor televisi.

Dampak dari Citizen Journalism tidak akan berpengaruh dengan kontributor yang memiliki pengalaman dan pengetahuan jurnalistik yang mendalam serta berkembangan mengikuti arus informasi saat ini. Kontributor harusnya lebih open minded dalam mengahadapi benturan yang terjadi di lapangan dengan $c j$. Informan sendiri mengaku belum pernah bertemu dengan $c j$ khususnya Net CJ.

Penyimpangan yang dilakukan Citizen Journalism sudah melanggar kode etik jurnalistik yang di pegang teguh oleh jurnalis. Sayangnya wadah yang harusnya bisa dipergunakan dengan baik dan semestinya, malah disalah gunakan oleh beberapa orang yang mementingkan dan menguntungkan dirinya sendiri hingga berimbas kepada nama baik jurnalis juga media. Pada dasarnya $c j$ memiliki keleluasan dalam mencari berita bahkan tidak ada batasan bagaimana tanggapan informan mengenai hal tersebut.

Mengenai hal ini peneliti berpendapat perlu adanya sosialisasi mengenai kode etik jurnalistik kepada masyarakat awam, karena arus informasi saat ini semakin pesat bahkan saat ini informasi yang masuk tidak terkontrol lagi. Adapun saran atau masukan untuk perbaikan citizen journalism dan medianya.

Kritik dan saran untuk perbaikan Citizen Journalism saat ini, adalah perlu adanya pengetahuan masyarakat mengenai dasar jurnalistik dan bagaimana Citizen Journalism yang sebenarnya. Informan juga mengharapkan untuk media yag memproduksi program Citizen Journalism agar lebih tegas dalam memberi aturan hinga tidak terjadi kasus yang menyimpang dan merusak dunia jurnalistik.

Citizen journalism adalah masyarakat biasa yang menyalurkan aspirasinya berupa informasi video ke media massa secara langsung. Perannya sangat membantu media televisi maupun kontributor televisi untuk mendapatkan berita dari berbagai daerah yang tidak terjangkau, karena luasnya wilayah media televisi tidak mempunyai banyak mitra kerja yang menjaga setiap titik wilayah Indonesia. Media televisi hanya mampu 
menugaskan kontributornya tiap daerah minimal dua atau tiga orang saja. Semakin berkembangnya citizen journalism saat ini yang tidak terkendali menimbulkan berbagai dampak baik positif maupun negatif. Hal ini berdampak dengan kontributor televisi di lapangan yang merasakan langsung berdampingan dengan citizen journalism. Kasus-kasus yang di dapatkan oleh kontributor berupa penyimpanagan citizen journalism yang mengatasnamakan suatu media, penyalahguanaan marchantdise yang diberikan pihak media dan memasuki area wajib kontributor yakni instansi pemerintah.

Dari hasil wawancara tidak ada aturan tegas dari pihak media untuk mengarahkan citizen journalism. Umumnya pihak media hanya mengedepankan hasil kwalitas video yang dibuat, namun tidak ada aturan atau batasan mengenai wilayah peliputan, kategori berita yang lengkap dan aturan mengenai etika saat peliputan. Ditambah tidak ada komunikasi yang terjalin antar citizen journalism dengan kontributor televisi membuat perubahan sikap dari keduanya.

Kasus penyimpangan etika citizen journalism yang dirasakan oleh informan dapat dijelaskan dengan Teori Behaviorisme yang menjelaskan tentang perubahan tingkah laku sebagai hasil dari pengalaman dan faktorfaktor lingkungan yang mempengaruhinya. Artinya para citizen journalism melakukan perubahan prilaku karena didukung oleh media yang memberikan kebebasan dan pemberian marchantdise sehingga membuat diri mereka merasa menjadi bagian dari media tersebut.

Hal ini didapatkan langsung dari pengalaman informan baik dari informan kontributor televisi maupun citizen journalism. Selain itu dari hasil pengamatan pengalaman keduanya peneliti mendapatakan hasil bahawa diantara kontributor televisi dengan citizen journalism tidak memiliki ikatan komunikasi yang baik hal ini dapat dijelaskan dengan Teori pendukung Persepsi yang menjelaskan bahwa jika persepsi tidak akurat maka komunikasi yang terjalin tidak akan efektif. Hal ini didapat dari semakin sering seseorang melakukan interaksi maka komunikasi yang dijalin semakain mudah dan baik. Persepsi didasari dari proses penginderaan, atensi, dan interpertasi dan diakhiri dengan pengamatan. Artinya, sebelum kontributor menyatakan persepsinya dirinya melihat, mendengar dan merasakan langsung apa yang dilakukan oleh citizen journalism dan mengamati dari berbagai hal yangberhubungan langsung dengan citizen journalism, hingga akhirnya menjelaskan persepsi mereka terhadap keberadaan citizen journalism yang umumnya cenderung mengarah kepada negatif kepada personalnya saja namun tidak kepada peran atau wadah yang dilakukan citizen journalism untuk perkembangan media saat ini.

\section{SIMPULAN}

Keberadaan Citizen Journalism menimbulkan banyak persepsi dari kontributor, yang umumnya menerima dan merasakan peran Citizen Journalism. Namun Citizen Journalism terlalu bebas dan di tunjang dengan apresiasi yang kuat dari pihak media, membuat $c j$ melupakan statusnya sebagai warga biasa. Saat ini wadah Citizen Journalism dijadikan perkerjaan utama dan juga alat pemanfaatan untuk mendapatakan keutungan lebih dengan menggunakan nama besar sebuah media. Selain itu tidak ada batasan wilayah membuat $c j$ bebas masuk ke instasi pemerintah hal ini nantinya akan membuat buruk nama media juga kontributor yang bertugas menanggung jawabi wilayah tersebut. Tidak adanya pola komunikasi menjadi hal utama kesalahpahaman kedua belah pihak sehingga terbentuk sikap negatif saat keduanya bertemu dalam satu tempat. Faktor keberadaan Citizen Journalism yakni semakin berkembangnya teknologi sehingga memudahkan masyarakat untuk merekam suatu kejadian dengan menggunakan 
Handphone. Ditambah dengan pesatnya perkembangan media sosial seperti Facebook, Instagram, Twitter hingga You Tube membuat media televisi tertarik untuk membuka wadah yang menampung aspirasi masyarakat berupa video yang langsung di tayangankan oleh stasiun televisi. Selain itu materi juga menjadi faktor masyarakat tertarik untuk menjadi Citizen Journalism, karena stasiun televisi memberikan bayaran tiap berita video yang di tayangkan pihak televisi. Etika menjadi faktor kemunculan kasus yang dilakukan Citizen Journalism hal ini diungkapkan oleh kontributor maupun cj. Umumnya penyimpangan etika yang dilakukan CJ berupa, menyalahgunkan atribut yang diberikan oleh pihak televisi, mengatasnamakan media, meliput ke area instansi pemerintah hingga melakukan pemerasan. Sampai saat ini tidak ada aturan yang menegaskan bagaimana peran $c j$ sebenarnya dan bagaimana peraturan yang harus ditaati $c j$.

\section{DAFTAR PUSTAKA}

Afrizal. (2014). Metode Penelitian Kualitatif: Sebuah Upaya Mendukung Penggunaan Penelitian Kualitatif Dalam Berbagai Disiplin Ilmu. PT Raja Grafindo Persada, Jakarta

Arikunto, S. (2006). Prosedur Penelitian Suatu Pendekatan Praktik. Rineka Cipta. Jakarta

Bungin, B. (2006). Sosiologi Komunikasi. Teori, Paradigma, dan Diskursus Teknologi Komunikasi di Masyarakat. Jakarta. Kencana Prenada Media Group.

Effendy, O.U. (2007). Ilmu Komunikasi, Teori dan Praktek. Remaja Rokasjaya. Bandung (2011). Ilmu Komunikasi, Teori dan Praktek. Remaja Rokasjaya. Bandung

Hikmat, M.M. (2011). Metode Penelitian: Dalam Perspektif Ilmu Komunikasi dan Sastra. Graha Ilmu, Bandung

Mulyana, D. (2007). Ilmu Komunikasi Suatu Pengantar. PT. Remaja Rosdakarya. Bandung

Morrisan, (2011). Manajemen Media Penyiaran: Strategi Mengelola Radio dan Televisi. Prenada Media Group. Jakarta
Nugraha, P, (2012). Citizen Journalism: pandangan, pemahaman dan pengalaman. Kompas. Jakarta

Pujileksono, S. (2015). Metode Penelitian Kualitatif. Kelompok Intrans Publishing. Malang.

Rakhmat, J. (2011). Psikologi Komunikasi. Cet. Ke27. PT. Remaja Rosdakarya, Bandung

Sugiyono. (2014). Metode Penelitian Pendidikan Pendekatan Kuantitatif, Kualitatif Dan R\&D. Alfabeta. Bandung

\section{Sumber Internet}

http://repository.fisipuntirta.ac.id/313/6/skripsi\%2 orevisi\%20\%28Repaired\%29.pdf diakses pada 5 September 2017 pukul 19.30 WIB

http://eprints.undip.ac.id/7226/1/journalism_glob alisasi_informasi.pdf diakses pada 5 September 2017 pukul 20.00 WIB

https://hanifrahm.wordpress.com/2012/o6/o1/teor i-behavioral-dan-kognitif/ diakses pada 5 September 2017 pukul 21.0o WIB

http://etikaprofesidanprotokoler.blogspot.co.id/2 oo8/o3/pengertian-etika.html diakses pada 5 September 2017 pukul 21.30 WIB

http://namanyajugaanakmuda.wordpress.com diakses pada 5 September 2017 pukul 21.45 WIB

http//jurnalis-televisi diakses pada 5 September 2017 pukul 22.0o WIB

E-jurnal journalism_globalisasi_informasi.pdf diakses pada $6 \quad$ September 2017 pukul 10.00 WIB 